\title{
Perencanaan Strategis Program Kampanye Public Relations Narasi TV Melalui Hastag \#Jadipaham
}

\author{
SyaWALIA PUtri Chafilaudina \& ASEP SOEgIARTO
}

Program Studi Hubungan Masyarakat, Fakultas IImu Sosial, Universitas Negeri Jakarta E-mail: syawaliaputri70@yahoo.co.id \& asep-sugiarto@unj.ac.id | Hp: 087787148724 \& 085221391014

Abstrak

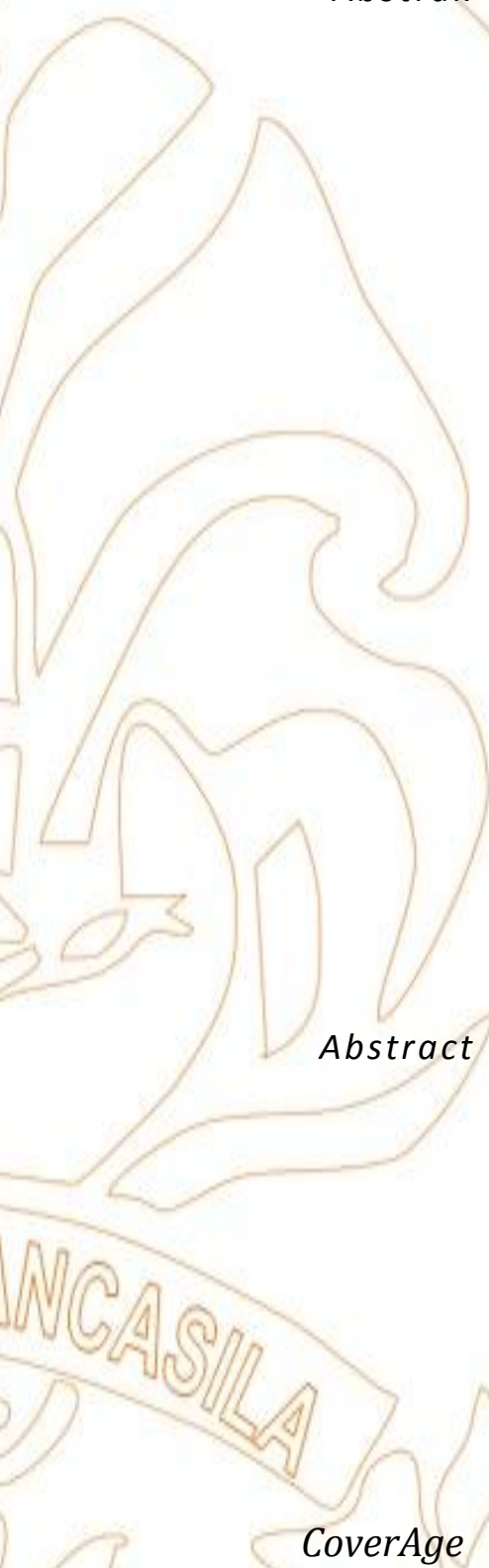

Journal of Strategic Communication

Vol. 12, No. 1, Hal. 40-51 September 2021

Fakultas Ilmu Komunikasi, Universitas Pancasila
Banyaknya masyarakat mengkonsumsi berita yang simpang siur mengenai pandemi Covid-19 merupakan sebuah pertanda bahwa dampak yang ditimbulkan dari adanya pandemi ini sudah merambat di berbagai bidang. Demi merespon permasalahan tersebut, Narasi TV yang merupakan collaborative media hadir melalui program kampanyenya yang disebut dengan kampanye \#JadiPaham melalui media sosialnya. Kampanye ini juga dibuat lantaran adanya kebutuhan untuk membentuk brand identity dari perusahaannya tersebut. Penelitian ini bertujuan untuk mengetahui perencanaan program kampanye \#JadiPaham yang dibuat oleh Narasi TV. Penelitian ini menggunakan pedekatan kualitatif dengan motode deskriptif. Data yang didapat dari penelitian ini diperoleh menggunakan teknik wawancara, observasi, dan dokumentasi. Hasil penelitian menunjukan perencanaan strategis kampanye \#JadiPaham dilakukan dengan berbagai tahap mulai dari riset dan analisis, menentukan tujuan dan strategi, menentukan taktik komunikasi dan implementasi, serta melakukan evaluasi setiap tiga bulan sekali. Selain itu, dengan adanya penelitian ini diharapkan dapat menjadi sumber referensi bagi penelitian selanjutnya serta lebih banyak untuk dikembangkan lagi menggunakan sumber dan teori lain yang berkaitan dengan perencanaan kampanye public relations.

Kata kunci: Perencanaan Strategis, Kampanye Public Relations, Kampanye \#JadiPaham

The number of people consuming a confusing news about the Covid-19 pandemic is a sign that the impact of this pandemic has spread in various ways. To respond these problems, Narasi TV, which is a collaborative media, is present through campaign program called the \#JadiPaham in its social media. This campaign was also created because of the need of brand identity forthe company. This study aims to determine the planning of the \#JadiPaham campaign program made by Narasi TV. This study uses a qualitative approach with a descriptive method. The data obtained from this study were using interview, observation, and documentation techniques. The results showed that the \#JadiPaham campaign planning was carried out in various stages ranging from research and analysis, determining goals and strategies, determining communication and implementation tactics, and conducting evaluations every three months. In addition, this research is expected to be a reference for further research and more to be developed using other sources and theories related to public relations campaign planning.

Keywords: Strategic Planning, Public Relations Campaign, \#JadiPaham Campaign 


\section{PENDAHULUAN}

Pandemi Covid-19 telah memberikan banyak perubahan bagi seluruh kehidupan masyarakat di berbagai belahan dunia. Perubahan yang timbul tidak hanya berdampak bagi kesehatan semata, namun sudah menjalar di berbagai bidang, salah satunya di bidang informasi. Saat ini, informasi dan berita mengenai pandemi Covid-19 sedang banyak dicari oleh para pengguna media digital. Namun sayangnya, pemberitaan yang ada di media justru banyak yang mengalami simpang siur. Dilansir dari website aptika.kominfo.go.id, hingga 5 Mei 2020 sudah terdapat 1.401 konten hoax dan disinformasi Covid-19 yang beredar di masyarakat (Yusuf, 2020).

Masyarakat yang terbiasa mengkonsumsi berita hoax cenderung akan memperkeruh suasana karena tanpa memahami konteks permasalahan dari sebuah informasi yang kemudian informasi tersebut langsung disebarkan. Selain itu, penyebaran berita yang belum tentu diketahui kebenarannya juga disebabkan oleh faktor rendahnya tingkat literasi yang ada di masyarakat (Herlambang, 2020). Oleh karena itu, Untuk menyelesaikan persoalan tersebut, diperlukan media yang dapat memberikan konteks pemahaman terhadap sebuah informasi dari berbagai perspektif agar tidak menyebabkan beredarnya berita yang simpang siur.

Narasi TV adalah salah satu perusahaan startup media berbasis digital. Melalui pilar content, community dan collaboration, Narasi TV memiliki visi untuk memberdayakan ruang berpendapat, memperkaya perspektif, dan mendorong terciptanya gerakan untuk membentuk generasi yang lebih baik. Awal tahun 2021 ini, Narasi TV sedang menggalakan sebuah kampanye tahunan yang bertajuk \#JadiPaham melalui media sosialnya sebagai ajakan kepada para khalayak untuk memahami konteks dari sebuah isu dan peristiwa sebelum mengkonsumsi dan menanggapi informasinya.

Kampanye \#JadiPaham ini juga mengajak seluruh tim internal Narasi TV agar dapat membuat konten yang sesuai dengan karakteristik khalayaknya. Selain itu, dengan adanya output dari kampanye ini, baik berupa konten maupun event, diharapkan seluruh khalayak Narasi TV akan mendapatkan dan memahami sebuah wawasan dari sudut pandang yang baru.

Adanya kampanye ini juga merupakan upaya dari tim Brand Communication Narasi TV untuk memenuhi kebutuhan dalam membentuk brand identity dari Narasi TV. Karena sebelum dibentuknya kampanye ini, Narasi TV belum memiliki sebuah hal yang dapat menjadi identitas sebagai pembeda dengan perusahaan lainnya. Dalam sebuah perusahaan, brand identity tentu saja diperlukan untuk mengidentifikasi dan membedakan dengan perusahan lainnya. Terlebih lagi, Narasi TV merupakan perusahaan yang bergerak di bidang digital tentu memerlukan adanya loyalitas khalayak. Dengan diadakannya kampanye ini, Narasi TV ingin khalayaknya menemukan konten yang sesuai dengan ketertarikan dan kebutuhan mereka dengan memberikan konten yang penting untuk dipahami. Narasi TV juga berharap khalayak untuk ikut berpartisipasi dalam pembuatan konten maupun komunitas.

Di sisi lain, adanya program kampanye ini, tentu terdapat peranan yang besar dari para praktisi public relations didalamnya. Public relations di sini merupakan bagian dari sebuah perusahaan yang memiliki tujuan komunikasi, seperti mendirikan pemahaman publik, meningkatkan citra perusahaan atau instansi, membangun opini publik yang bernilai positif, serta membentuk goodwill dan kerja sama (Kriyantono, 2008).

Begitu pula dalam kampanye \#JadiPaham ini juga dibuat oleh salah satu divisi di Narasi TV yaitu divisi Brand Communication yang berperan penting dalam melakukan perencanaan strategis program kampanye \#JadiPaham. Divisi Brand Communication tentu harus memperhatikan segala aspek perencanaan dengan cermat dan hati-hati agar tujuan dari kampaye ini dapat terwujud dan dapat terhindar dari kegagalan yang menyebabkan krisis.

Jika dilihat, ada beberapa contoh perusahaan yang gagal dalam membuat program kampanye sehingga berujung terjadinya krisis. Salah satunya adalah perusahaan Sprite. Pada tahun 2016, Sprite pernah membuat sebuah kampanye di Irlandia menggunakan tagline yang berbunyi "youre not popular, youre easy" yang dipopulerkan melalui hastag \#BrutallyRefreshing. Namun, adanya kampanye ini justru menjadi kontroversi bagi sebagian besar masyarakat Irlandia karena dinilai merendahkan perempuan. Akibatnya banyak masyarakat yang protes menyalahkan Sprite melalui media sosial. Kasus ini berakhir dengan permohonan maaf yang disampaikan oleh juru bicara dan melakukan penarikan atas iklan yang sudah tersebar untuk mempromosikan kampanye ini (Alexander, 2016).

Adanya contoh kasus tersebut telah membuktikan bahwa penting sekali melakukan perencanaan sedetail mungkin jika ingin mengadakan se- 
buah program kampanye. Setiap praktisi public relations juga dituntut untuk membuat program yang sangat relevan dengan visi, misi dan nilai perusahaan serta kondisi lingkungan terkini. Hingga sejauh ini, kampanye \#JadiPaham masih terus berjalan dan tim Brand Communication Narasi TV masih terus berupaya agar seluruh output dari kampanye ini dapat tersampaikan kepada seluruh khalayaknya.

Hal inilah yang akhirnya membuat peneliti merasa tertarik untuk melakukan penelitian mengenai perencanaan strategis kampanye public relations yang dilakukan Narasi TV. Berdasarkan latarbelakang di atas, telah dibuat rumusan masalah dalam penelitian ini, yaitu: Bagaimana Perencanaan Strategis Program Kampanye Public Relations Narasi TV Melalui Hastag \#JadiPaham? Adapun tujuan dari adanya penelitian ini adalah untuk mengetahui perencanaan strategis program kampanye public relations Narasi TV melalui hastag \#Jadipaham.

\section{TINJAUAN PUSTAKA}

\section{Public Relations}

Public relations dapat didefinisikan sebagai fungsi manajemen yang bertujuan untuk menciptakan dan menjaga hubungan yang baik antara organisasi dengan publiknya, serta sangat mempengaruhi keberhasilan disebuah organisasi (Cutlip et al, 2017). Sedangkan Menurut Frank Jefkins (Soemirat \& Ardianto, 2005), public relations adalah proses keseluruhan komunikasi terencana antara suatu perusahaan atau instansi dengan publiknya baik ke dalam maupun keluar dengan tujuan yang terperinci dan berlandaskan pada saling pengertian (Lengkong, 2017).

Pada dasarnya, public relations memang sangat dibutuhkan di setiap perusahaan karena $p u-$ blic relations juga merupakan salah satu penentu keberhasilan sebuah perusahaan. Hal ini membuat setiap tujuan public relations juga merupakan tujuan dari organisasinya sendiri. Untuk mewujudkan tujuan-tujuan tersebut tentu harus diimplementasikan dalam kegiatan public relations.

Secara sederhana, adapun ruang lingkup aktivitas praktisi public relations di perusahaan atau instansi biasanya mencangkup: 1) Membangun hubungan dengan publik internal, yaitu orangorang yang masih menjadi bagian dari perusahaan atau instansi. Misalnya dalam membuat dan menjalankan sebuah kebijakan, praktisi public relations harus mampu untuk melakukan identifikasi terkait hal-hal yang berpotensi untuk memunculkan gam- baran yang kurang baik dalam masyarakat. 2) Membangun hubungan ke dengan publik eksternal, seperti masyarakat. Praktisi public relations di sebuah lembaga atau organisasi harus bisa membangun citra yang positif sebagai pandangan masyarakat luar terhadap organisasi atau perusahaan yang diwakilinya (Ruslan, 2016).

\section{Kampanye Public Relations}

Kampanye public relations merupakan sebuah kegiatan yang diinisiasi oleh sebuah lembaga dan organisasi dengan tujuan menumbuhkan kesadaran dan pengetahuan target khalayak untuk meningkatkan persepsi atau opini positif agar mendapatkan kepercayaan dan image yang baik dari khalayak dengan mengkomunikasikan pesan secara terperinci melalui serangkaian kegiatan komunikasi dan rentang waktu tertentu serta berkala (Putri \& Larasati, 2014). Dengan kata lain, kampanye public relations adalah suatu kegiatan komunikasi yang terstruktur secara berkala, terdapat sebuah pesan dan tujuan tertentu, seperti memperoleh citra dan opini yang baik dari khalayak sasaran kampanye. Kampanye public relations juga erat kaitannya dengan komunikasi persuasif, yaitu komunikasi yang dilakukan agar khalayak dapat berperilaku yang sesuai dengan apa yang diharapkan dari adanya kampanye tersebut.

Adanya kampanye public relations ini tentu didasarkan pada tujuan tertentu. Dikutip dari Newsom, Scoot \& Turk (1997) dalam Ruslan (2013a), Patrick Jackson yang merupakan senior pendiri dan konsultan public relations internasional News Hampshire merumuskan beberapa tujuan kampanye public relations sebagai berikut: 1) Public Awareness, yaitu membuat kesadaran publik yang berkaitan dengan bidang sosial. 2) Offer Information, memberkan sebuah informasi yang berkaitan dengan program kampanye kepada khalayak yang tertarik. 3) Public Education, memberikan pemahaman kepada khalayak dalam mengekspresikan opininya secara emosional dengan tidak melupakan etika dan batas wajar. 4) Reinforce the Attitude and Behavior, mempererat sebuah nilai atau mengubah khalayak dari sisi perilaku melalui persetujuan yang dilakukan oleh komunikator. 5) Behavior Modification, melakukan perubahan perilaku khalayak dengan meyakinkan program keselamatan sosial tertentu.

\section{Perencanaan Kampanye Public Relations}

Untuk merencanakan sebuah program public relations, Ronald D. Smith (2013) dalam bukunya yang 
berjudul Strategic Planning for Public Relations, mencoba menjelaskan proses perencanaan program public relations dengan sebuah model yang disebut The Nine Steps of Strategic Public Relations.Proses perencanaan dengan menggunakan model ini dibagi kedalam empat bagian besar yang terdiri dari sembilan tahap perencanaan kampanye public relations.

Pertama adalah formative research, yaitu melakukan riset dengan maksud agar program yang dibuat dapat berlandaskan dengan fakta yang ada dan menghindari istilah "shooting in the dark". Lebih lanjut, Cameron (1992) menambahkan bahwa adanya penelitian dapat dapat mengoptimalkan sebuah perencanaan strategis dan akuntabilitas dalam praktik hubungan masyarakat. Dalam melakukan riset, ada beberapa hal yang harus, yaitu:

1) Analisis situasi. Merupakan kegiatan mengidentifikasi situasi yang sedang dihadapi perusahaan. Hal ini mencangkup tantangan atau masalah yang sedang dihadapi, dan mencari celah untuk menemukan jalan keluarnya.

2) Analisis organisasi. Kegiatan mengidentifikasi organisasi, baik dengan cara melakukan analisis SWOT (Strengths, Weakness, Opportunities, and Threats), maupun analisis lingkungan internal, eksternal dan persepsi publik.

3) Analisis publik. Tahap ini merupakan tahap analisis dan Identifikasi publik yang memiliki interaksi dengan organisasi.

Kedua adalah strategy, tahap ini merupakan tahap penyusunan perencanaan keseluruhan yang meliputi tujuan pencapaian dan bagaimana mengambil langkah untuk mencapai tujuannya. Dalam penyusunan strategi tentu didasarkan pada riset yang telah dilakukan pada tahap sebelumnya. Untuk tahap strategi ini terdapat tiga hal yang harus ditempuh, yaitu:

1) Menentukan tujuan dan objektif. Tujuan adalah pernyataan dari hasil spesifik yang diharapkan untuk publik, sedangkan objektif merupakan pernyataan terukur yang berlandaskan pada tujuan untuk mengetahui tingkatan tertentu pada level awareness (kesadaran), acceptance (penerimaan), dan action (aksi).

2) Merumuskan strategi aksi dan respon. Dibagi berdasarkan strategi proaktif dan re- aktif. Strategi proaktif yaitu strategi yang dibuat berdasarkan inisiatif organisasi, meliputi aksi (organizational performance, audience participations, special event, sponsorship, dan activism) dan komunikasi (publicity, generating news, newsworthy information and transparent communication, dan media theory \& public relations). Sedangkan strategi reaktif merupakan Strategi yang dirancang ketika terdapat masalah atau krisis di sebuah organisasi (meliputi: preemptive action, offensive response, defensive response, diversionary response, vocal commiseration, rectifying behavior, dan deliberate inaction).

3) Mengembangkan strategi pesan. Ketika ingin menyampaikan pesan kampanye, maka yang harus dilakukan adalah mengidentifikasi khalayaknya terlebih dahulu. Kemudian untuk berkomunikasi dengan khalayak tentunya hal yang harus diperhatikan adalah orang yang akan menyampaikan pesan, tampilan dan struktur pesan yang akan disampaikan, kalimat yang akan digunakan, hingga penggunaan simbolnya

Ketiga adalah tactics, merupakan tahapan untuk melakukan implementasi dari strategi. Dalam fase ini, hal yang harus dilakukan meliputi:

1) Menentukan taktik komunikasi. Merupakan cara dan media yang digunakan dalam menyampaikan pesan. Pembagian jenis taktik komunikasi meliputi: komunikasi interpersonal (yaitu proses interaksi tatap muka yang melibatkan individu secara personal), media organisasi (media yang dibuat atau dipublikasikan oleh organisasi), media berita (menyediakan dan memberikan informasi pesan organisasi kepada khalayak yang lebih luas), dan Iklan serta media promosi (media yang dikendalikan, umumnya di luar organisasi, yang juga menawarkan akses ke khalayak luas).

2) Implementasi rencana strategis. Merupakan tahap untuk menetapkan jadwal dan anggaran untuk implementasi dari program yang ingin dijalankan.

Terakhir adalah evaluative research, yaitu melakukan riset untuk mengukur efektivitas dari strategi dan taktik komunikasi yang dipakai agar tujuan dan sasaran yang sudah ditetapkan dapat tercapai dengan baik. Dalam tahap ini hal yang dilakukan adalah dengan mengevaluasi rencana stra- 
tegis, yaitu menentukan aspek dan kriteria yang akan di evaluasi, menentukan waktu evaluasi, dan sistem pelaksanaan evaluasinya.

\section{Keterkaitan Antar Konsep}

Pada dasarnya, mempertahankan citra yang positif bagi perusahaan dan membina hubungan yang baik dengan khalayak merupakan tujuan utama dari setiap kegiatan yang dilakukan oleh praktisi public relations. Salah satu kegiatan yang dilakukan oleh praktisi public relations adalah dengan membuat kegiatan kampanye public relations, karena sebagaimana telah dijelaskan diatas, bahwa kampanye public relations erat kaitannya dengan peningkatan kesadaran dan pengetahuan khalayak. Hal ini dilakukan agar tercipta opini yang baik dan kepercayaan dari masyarakat kepada sebuah perusahaan atau instansi.

Oleh karena itu, dalam membuat program kampanye, tentu saja harus dalam perencanaan yang matang agar mendapatkan hasil yang sesuai sasaran. Perencanaan yang dimaksud adalah keseluruhan tahap mulai dari riset, penentuan strategi dan taktik, hingga evaluasi. Dalam hal ini para praktisi public relations harus dilibatkan dalam proses perencanaan kampanye, karena hal tersebut mencangkup tugas dan peran praktisi public relations. Dengan memperhatikan keseluruhan tahapan yang ada, sebuah program kampanye dapat terlaksana dengan baik sehingga mendapat feedback yang positif berupa peningkatan citra sebuah perusahaan.

Studi penelitian mengenai perencanaan strategis program public relations perlu diteliti, karena kegiatan perencanaan program public relations berfungsi agar seluruh kegiatan dapat terencana sehingga dapat sesuai dengan tujuannya. Penelitian ini diteliti untuk mengetahui tahapan perencanaan yang dilakukan agar terciptanya program kampanye yang sukses.

Penelitian yang sedang diteliti adalah membahas mengenai program kampanye public relations yang diselenggarakan oleh Narasi TV melalui hastag \#JadiPaham melalui media sosialnya. Secara Umum, Taprial dan Kanwar (2012) dalam Asih dan Rosit (2020) menjelaskan bahwa media sosial merupakan media yang memungkinkan seseorang untuk berbagi konten, berita, foto dan lain lain dengan orang lain. Jadi adanya kampanye ini bertujuan mengedukasi masyarakat untuk memahami sebuah isu sebelum mengkonsumsi informasinya melalui konten konten yang akan dibagian Narasi TV. Selain itu, kampanye ini juga bertujuan agar tim internal Narasi TV dapat memahami khalayaknya sehingga dapat menciptakan output yang sesuai dengan kebutuhan khalayak. Terselenggaranya kampanye ini tentu memiliki perencanaan yang cukup matang karena kampanye ini diselenggarakan dalam periode waktu yang cukup lama.

Dalam penelitian perencanaan kampanye public relations \#JadiPaham, Peneliti menggunakan teori The Nine Steps of Strategic Public Relations yang dikemukakan oleh Ronald D. Smith (2013). Teori ini mencangkup sembilan langkah perencanaan program public relations yang dibagi kedalam empat kategori besar, yaitu riset, penentuan strategi, penentuan aksi, dan evaluasi. Teori ini menjelaskan secara detail bagaimana merencanakan sebuah program public relations yang baik, khususnya program kampanye, sehingga peneliti dapat mengetahui bagaimana proses perencanaan program public relations yang dilakukan Narasi TV agar mendapatkan hasil penelitian yang sesuai dengan tujuan penelitian.

\section{METODE}

Pendekatan penelitian merupakan seluruh langkah yang ditempuh dalam sebuah penelitian yang diawali dari membuat rumusan masalah hingga kesimpulan (Fauziana, 2017:60). Pada penelitian ini, peneliti menggunakan pendekatan kualitatif. Menurut Denzin dan Lincoln (Tohirin, 2016), pendekatan kualitatif adalah proses melakukan penelitian yang memakai latar ilmiah untuk menguraikan fenomena yang sudah terjadi dan tempuh melalui cara yang meliputi segala metode yang ada.

Sedangkan metode penelitian merupakan langkah yang ditempuh untuk mengumpulkan dan menganalisis suatu objek atau subjek demi mendapatkan jawaban dari pertanyaan sebuah penelitian yang dapat dipertanggungjawabkan segala keabsahannya (Ruslan, 2013b). Pada penelitian ini, peneliti menggunakan metode penelitian deskriptif, yaitu cara yang digunakan untuk meneliti tentang status sekumpulan manusia, sebuah objek, kondisi, maupun sistem pemikiran serta suatu kelas kejadian di masa kini. Tujuan dari adanya metode deskriptif ini adalah untuk menggambarkan, mendeskripsikan fakta dan sifat dari fenomena yang sedang diselidiki secara sistematis, akurat, dan faktual (Ayuningrum, 2020).

Peneliti menggunakan penelitian deskriptif kualitatif dikarenakan dalam penelitian yang berjudul "Perencanaan Strategis Program Kampanye Public Relations Narasi TV Melalui Hastag \#JadiPaham" ini, peneliti ingin menjabarkan tahapan pe- 
rencanaan kampanye yang dilakukan Narasi TV melalui kampanye \#JadiPaham dengan melalui teknik wawancara, observasi, dan dokumentasi yang hasilnya berupa deskripsi dari setiap tahapan yang diamati berdasarkan teori yang digunakan dalam penelitian ini.

Seperti yang sudah dijelaskan sebelumnya, cara yang dilakukan dalam mengumpulkan data dalam penelitian ini adalah melalui wawancara, observasi, dan dokumentasi. Metode wawancara dapat didefinisikan sebagai proses mengumpulkan data dengan melibatkan presentasi rangsangan lisan verbal yang dibalas dengan tanggapan lisan juga (Tarjo, 2019). Dalam hal ini peneliti mewawancarai key informant, yaitu Susangga Surya Alam selaku Head of Brand Communication Narasi TV, dan dua orang informan lainnya, yaitu Ajeng Nur Annisa yang merupakan bagian dari Brand Communication-Social Media Specialist (internship) dan Arinie Hudaya yang merupakan followers Narasi TV.

Sedangkan observasi merupakan sebuah proses yang diawali dengan pengamatan dan dilanjutkan dengan proses mencatat yang bersifat terukur, logis, faktual, dan rasional terhadap segala fenomena baik dalam keadaan sebenarnya maupun tidak. Dalam hal ini observasi yang dilakukan oleh peneliti hanya melalui beberapa media sosial $\mathrm{Na}$ rasi TV. Hal ini dilakukan karena kampanye \#JadiPaham yang dilakukan oleh Narasi TV hanya melalui social media mirik Narasi TV.

Lebih lanjut, dokumentasi merupakan sebuah cara untuk mendapatkan data dari dokumen dokumen yang berasal dari arsip suatu instansi (Kristanto, 2018). Dalam hal ini, peneliti menggunakan beberapa arsip pribadi milik perusahaan seperti deck, timeline, dan arsip arsip lainnya untuk untuk menambahkan dan memperkuat hasil penelitian.

Kemudian dalam proses analisis data dalam penelitian ini menggunakan teori Miles dan $\mathrm{Hu}$ berman (1992). Dalam model ini, tahapan yang perlu dilakukan dalam melakukan analisis data yaitu:

1. Tahap reduksi data, yaitu tahap yang dimulai dengan melakukan rangkuman, memberikan kode, merumuskan temanya, mengelompokan dan menyajikan seluruh data yang telah didapatkan baik melalui wawancara, observasi, maupun rekaman ke dalam bentuk deskripsi kata-kata.

2. Tahap penyajian data, yaitu tahap kedua dalam melakukan analisis data di mana da- lam tahap ini peneliti mengkonstruksikan seluruh data sebagai dasar pengambilan keputusan. Tahap ini diawali dengan menganalisis segala proses reduksi data untuk memahami intinya. Kemudian penyajian datanya akan difokuskan ke dalam bentuk ringkasan yang terstruktur.

3. Tahap pengambilan kesimpulan, yaitu peneliti diharuskan untuk melakukan interpretasi dengan mengartikan data yang sudah diperoleh. Untuk memastikan kebenaran datanya, maka perlu melakukan perbandingan antara pola, tema, dan kelompoknya melalui triangulasi. Jika dari keseluruhan data saling berkaitan, maka peneliti langsung dapat menjalankan proses transformasi data (Tarjo, 2019).

Uji Keabsahan data dalam penelitian ini menggunakan teknik triangulasi sumber. Triangulasi sumber adalah proses membandingkan kembali tingkat kesahihan data dan informasi yang telah diambil dari berbagai sumber yang berbeda. Contohnya seperti membandingkan hasil wawancara dengan observasi atau dokumen, dan informasi yang disampaikan di depan umum dengan yang disampaikan secara pribadi (Firdaus \& Zamzam, 2018). Penetapan trianggulasi sumber sebagai uji keabsahan data ini didasarkan pada pengumpulan data penelitian ini menggunakan berbagai macam sumber seperti dokumentasi, observasi dan wawancara. Dalam melakukan wawancara, peneliti juga menggunakan lebih dari satu informan. Sehingga dari beberapa sumber yang didapatkan peneliti dalam pengumpulan data, peneliti bisa melakukan uji keabsahan data dengan teknik triangulasi sumber. Nantinya peneliti akan melakukan pengelompokan dan mendeskripsikan dari berbagai data yang sudah didapatkan dari berbagai sumber yang ditetapkan.

\section{HASIL DAN PEMBAHASAN}

Praktisi public relations memiliki peranan yang sangat diperlukan terutama dalam mempertahankan citra sebuah perusahaan atau instansi di tempatnya bekerja. Hal ini dapat dilakukan apabila setiap perusahaan bisa memaksimalkan peran public relations di dalamnya. Ada berbagai kegiatan yang dapat dilaksanakan oleh para praktisi public relations untuk meningkatkan citra positif, salah satunya dengan membuat program public relations. Namun untuk mengoptimalisasikan program tersebut, dibutuhkan proses perencanaan yang efektif melalui manajemen kehumasan. Selain un- 
tuk menghindari kesalahan, hal tersebut dilakukan agar program yang direncanakan dapat sesuai dengan tujuan dan target sasaran. Lebih lanjut perencanaan strategis dalam konteks public relations sangat penting untuk diterapkan demi terciptanya komunikasi antara perusahaan dan public yang saling mengungkan. Selain itu, adanya perencanaan strategis tentu dapat berkaitan dengan pencapaian visi misi dan tujuan perusahaan (Hasan Güllüpunar, 2013).

Seperti yang dilakukan oleh Narasi TV yang saat ini sedang meningkatkan performa dari brand identity melalui sebuah rangkaian kampanye yang disebut \#Jadi Paham. Kampanye \#JadiPaham merupakan salah satu kampanye yang diselenggarakan oleh Narasi TV di tahun 2021 dengan tujuan meningkatkan performa brand identity dan memperkenalkan produk konten Narasi TV dengan membangun kesadaran khalayak tentang pentingnya konteks dalam sebuah informasi. Melalui kampanye ini, Narasi TV juga akan melibatkan khalayak dalam membuat konten dengan membawa karakter khalayak agar tidak mudah terbawa arus informasi hoax.

Dalam pembuatannya, kampanye \#JadiPaham ini diinisiasi oleh divisi Brand Communication Narasi TV. Divisi Brand Communication adalah salah satu unit kerja yang berada di Narasi TV dan langsung berada di bawah Chief Executive Officer. Brand Communication memiliki fungsi untuk merumuskan dan membentuk produk, serta mengarahkan agar produk yang akan dipublikasi sesuai dengan nilai Narasi TV secara konten, tone, voice, dan look. Selain itu, divisi Brand Communication juga bertugas untuk berkoordinasi dengan lintas divisi dengan melakukan cross-check agar menyesuaikan output-nya sesuai dengan visi dan misi Narasi TV, membuat kampanye, memastikan segala output sesuai dengan campaign, dan merencanakan strategi komunikasi melalui sosial media.

Untuk menjalankan kampanye \#JadiPaham ini tentu divisi Brand Communications sudah melakukan perencanaan yang sangat matang mulai dari riset, penentuan strategi dan taktik, hingga perencanaan untuk evaluasi. Berikut ini adalah proses perencanaan strategis dalam membuat kampanye \#JadiPaham oleh Narasi TV:

\section{Formative Research}

Formative Research adalah fase awal yang dilakukan dalam membuat perencanaan sebuah program public relations. Terdapat tiga hal yang harus dilakukan didalam tahap ini, yaitu analisis situasi, analisis organisasi, dan analisis publik. Tahap pertama adalah analisis situasi. Dalam analisis situasi, divisi Brand Communication Narasi TV melihat bahwa adanya kebutuhan untuk membentuk brand identity. Selain itu, adanya gambaran situasi pandemi Covid-19 membuat masyarakat mengkonsumsi informasi yang masih simpang siur mengenai keberadaannya. Dari gambaran situasi tersebut, riset yang dilakukan berfokus pada kekurangan dalam mencukupi kebutuhan untuk membentuk brand identity Narasi TV dan juga hal yang ingin disampaikan kepada khalayak mereka.

Tahap kedua adalah analisis organisasi. Analisis organisasi dapat digambarkan bahwa Narasi TV merupakan perusahaan kolaboratif media di mana Narasi TV ingin aktif melakukan komunikasi dengan khalayaknya. Narasi TV selalu berprinsip pada tiga pilar, yaitu content, community, dan collaboration. Selain itu, dalam membuat setiap program dan kontennya, Narasi TV selalu mengedepankan nilai creative impactfull journalism yang berarti setiap program maupun konten yang diciptakan harus berdasarkan fakta yang bisa bernilai manfaat untuk khalayak dan dikemas dalam bentuk yang kreatif. Nilai creative impactfull journalism dapat diwujudkan apabila memenuhi tiga kriteria, yaitu understanding what matter, yang berarti memberikan konteks untuk dipahami khalayak mengenai perkembangan current affair yang sedang terjadi, pop culture with purpose yang berarti mendorong khalayak untuk memiliki perspektif terhadap peristiwa yang membentuk perkembangan sosial dan budaya, dan creative yang berarti mengeksplorasi perkembangan mulai dari ide hingga pengemasan produk yang kreatif.

Tahap ketiga adalah menganalisis publik yang merupakan target sasaran dalam program yang dibuat. Target sasaran dari kampanye \#JadiPaham adalah tim internal yang merupakan karyawan $\mathrm{Na-}$ rasi TV dan tim eksternal yang merupakan khalayak Narasi TV yang merupakan pengguna platform digital dengan rentang umur 18-35 tahun.

\section{Strategy}

Tahap penentuan strategi merupakan hal yang cukup penting karena di tahap ini praktisi public relations harus menyusun perencanaan keseluruhan berdasarkan riset yang dilakukan di tahap sebelumnya. Pada fase ini terdapat tiga tahap, yaitu menentukan tujuan dan objektif, memformulasikan aksi dan respon, dan mengembangkan strategi pesan.

Tahap penentuan tujuan dan objektif, yaitu 
fokus tujuan akhir pekerjaan kampanye \#JadiPaham ini adalah reputation management goals, yaitu terbentuknya brand identity Narasi TV. Disamping tujuan itu, akan muncul beberapa tujuan lain yang berkaitan dengan relationship management goals dan task management goals bagi Narasi TV, yaitu membangun interaksi dengan khalayaknya dan memberikan pemahaman khalayak mengenai konteks dari sebuah informasi. Selain itu, membuat strategi juga harus berdasarkan objektif (ketercapaian tujuan yang diukur berdasarkan tingkat awareness, acceptance, dan action). Jika dilihat dalam pengukuran objektivitas, tujuan dari kampanye \#JadiPaham ini dapat dikatakan mencapai level action atau aksi. Karena berdasarkan tujuan kampanye ini, Narasi TV ingin tim internal dapat membuat konten sesuai dengan kebutuhan khalayaknya, dan khalayak juga diharapkan dapat menjadi bagian dari komunitas untuk menjadi co-creator Narasi TV.

Selanjutnya, menyusun aksi dan respon, merupakan tahap dimana menyatukan kegiatan atau aksi dengan respon yang akan diterima. Strategi yang digunakan adalah strategi proaktif dengan meningkatkan performa organisasi dan partisipasi khalayak melalui digital activation. Hal ini dilakukan dengan cara menjalankan seluruh aset Narasi TV untuk memaksimalkan proses interaktif dengan khalayaknya. Selain itu, Narasi TV juga memunculkan produk produk baru dan juga memaksimalkan partisipasi khalayak untuk menjadi bagian dari komunitas Narasi TV. Dalam hal ini, aset yang dimaksud adalah berbagai akun instagram yang merupakan bagian dari Narasi TV, seperti @wmnbynarasi, @narasinewsroom,dan @getstarted.narasi yang sengaja dibuat untuk memperbanyak interaksi dengan khalayaknya dan dapat mengetahui karakteristik serta kebutuhan konten dari khalayaknya sendiri.

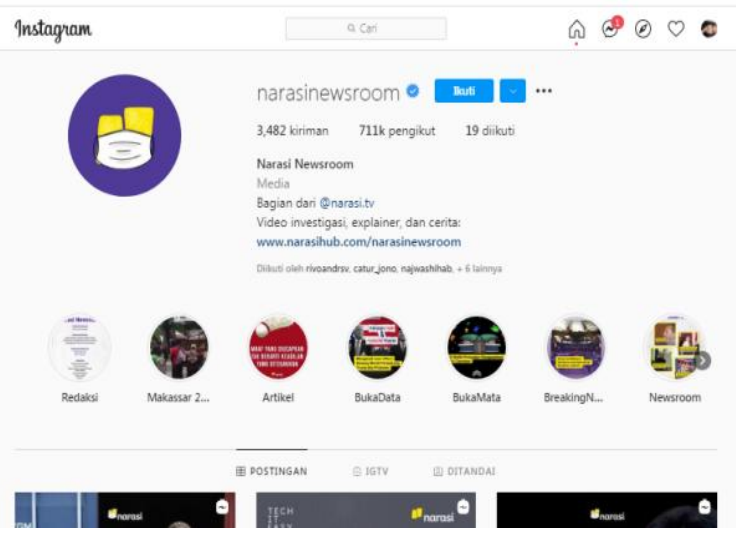

Gambar 1. Akun instagram @Narasinewsroom Sumber: Instagram @Narasinewsroom
Selain fokus pada performa organisasi dan partisipasi khalayak, Narasi TV juga bekerja sama dengan beberapa pihak untuk mensukseskan kampanye \#JadiPaham ini, diantaranya bekerja sama dengan Universitas Gajah Mada dengan membuat kelas kewirausahaan dan Institut Teknologi Bandung dengan menyelenggarakan event Indonesia Butuh Anak Muda.

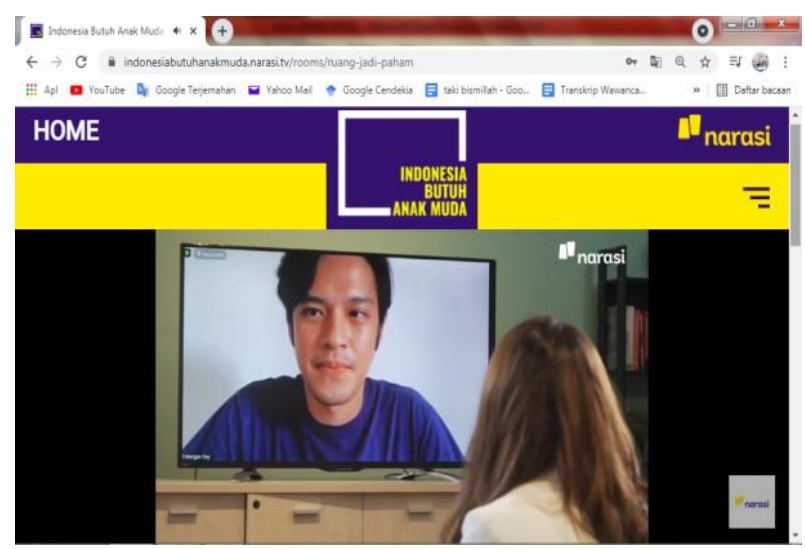

Gambar 2. Event Indonesia Butuh Anak Muda Bersama ITB

Sumber: https://indonesiabutuhanakmuda. narasi.tv/rooms/ruang-jadi-paham

Pesan tersebut tentunya disampaikan dari berbagai perspektif dan dikemas dalam tampilan konten yang mengandung visualisasi yang menarik agar mendapatkan perhatian dari khalayak.

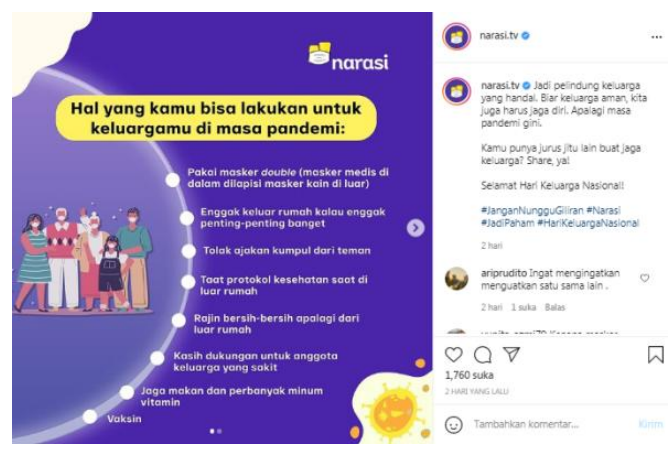

Gambar 3. Tampilan Pesan Melalui Visualisasi Sumber: instagram @Narasi.tv

Selain itu, dalam mengembangkan strategi pesan, juga erat kaitannya dengan pemilihan spokesperson sebagai orang yang bertugas menyampaikan pesan. Untuk beberapa program yang terdapat pembicaranya tentu selalu memperhatikan spokesperson-nya. Dalam beberapa program, sering kali Najwa Shihab terlihat sebagai spokesperson-nya. Selain itu juga ada Andini Effendi, Tasya 
Kamila, dan beberapa orang terkenal lainnya yang sering tampil dalam beberapa program yang ada di Narasi TV. Biasanya, acuan dalam pemilihan spokesperson adalah orang yang ahli dengan tema yang sedang diangkat, memiliki image yang baik, dan memiliki passion untuk sharing.

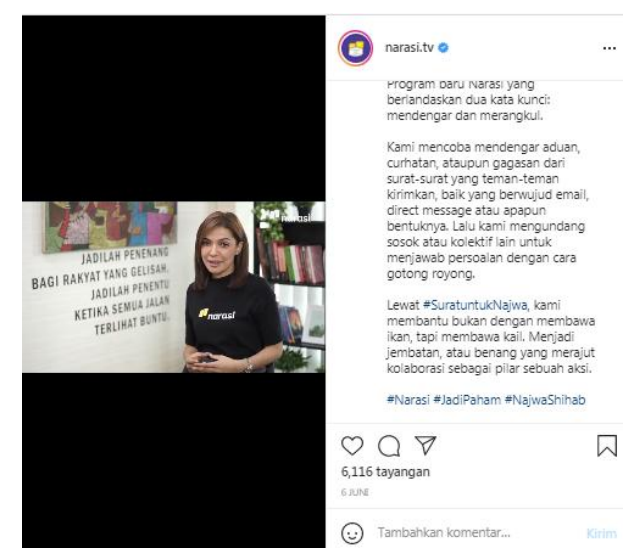

Gambar 4. Najwa Shihab yang Tampil Menjadi Spokespersons di salah satu Program Narasi TV Sumber: Instagram @narasi.tv

Pada intinya, pesan yang ingin diberikan dalam program kampanye ini adalah pesan yang mengandung nilai edukasi. Hal ini bertujuan agar menjadikan khalayak menjadi decision maker yang akan membentuk generasi society.

\section{Tactics}

Fase ini merupakan pemilihan taktik komunikasi dan melakukan implementasi rencana strategis. Dalam kampanye \#JadiPaham, salah satu taktik komunikasi yang dilakukan adalah dengan menggunakan komunikasi interpersonal. pendekatan ini dianggap sebagai pendekatan yang cukup efektif karena mendapatkan pemahaman khalayak yang lebih besar. Dalam hal ini, Narasi TV membuat program misalnya educational gathering, seperti webinar dan workshop, ataupun special event seperti Indonesia Butuh Anak Muda dan Playfest.

Tidak hanya itu, kampanye \#JadiPaham ini juga menggunakan pendekatan melalui media yang dapat dikontrol oleh organisasinya. Melalui website dan media sosial, seperti Instagram, Youtube, Facebook dan Twitter, Narasi TV sering menggunakannya untuk menyebarkan konten, membuat ruang berdiskusi, hingga melakukan promosi untuk berbagai event besar. Hal ini dilakukan karena Narasi TV merupakan perusahaan yang berbasis digital dan menggunakan media sosial sebagai ranah publikasinya. Selain itu, penggunaan hastag
\#JadiPaham pun juga selalu dilakukan setiap kali ada posting-an yang berkaitan dengan kampanye \#JadiPaham. Hal ini bertujuan untuk memudahkan khalayak menemukan berbagai macam konten dan informasi mengenai kampanye \#JadiPaham.

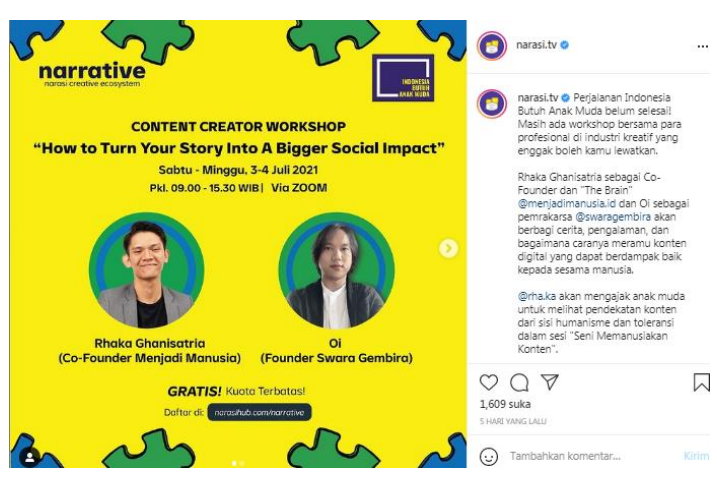

Gambar 5. Content Creator Workshop (Educational Gathering)

Sumber: Instagram @narasi.tv
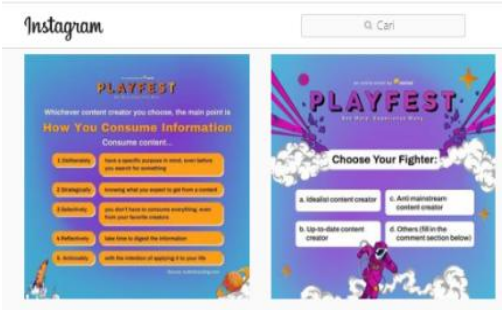

(A)
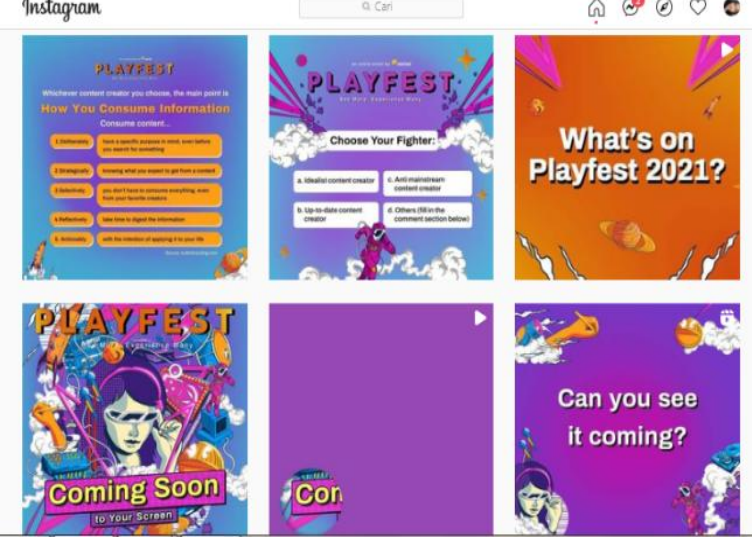

Gambar 6. Playfest Narasi (Special Event) Sumber: Instagram @playfestnarasi

Tidak hanya itu, kampanye \#JadiPaham ini juga menggunakan pendekatan melalui media yang dapat dikontrol oleh organisasinya. Melalui website dan media sosial, seperti Instagram, Youtube, Facebook dan Twitter, Narasi TV sering menggunakannya untuk menyebarkan konten, membuat ruang berdiskusi, hingga melakukan promosi untuk berbagai event besar. Hal ini dilakukan karena Narasi TV merupakan perusahaan yang berbasis digital dan menggunakan media sosial sebagai ranah publikasinya. Selain itu, penggunaan hastag \#JadiPaham pun juga selalu dilakukan setiap kali ada posting-an yang berkaitan dengan kampanye \#JadiPaham. Hal ini bertujuan untuk memudahkan khalayak menemukan berbagai macam konten dan informasi mengenai kampanye \#JadiPaham. 


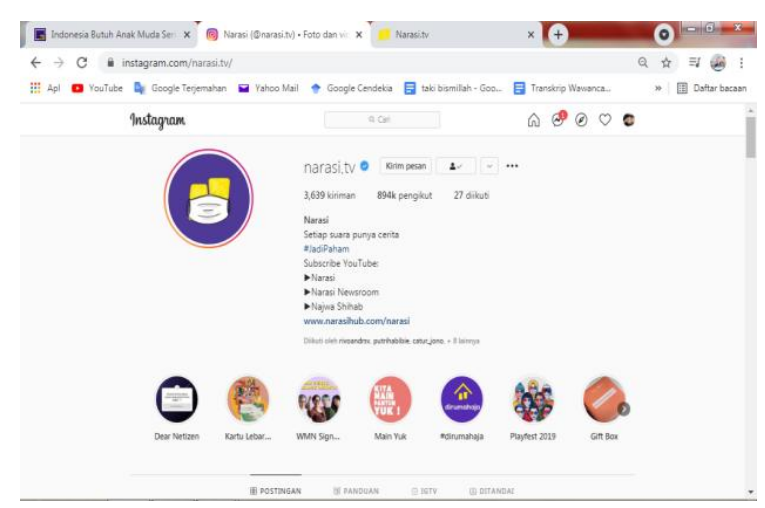

Gambar 7. Penggunaan media Instagram @narasi.tv Sumber: Instagram @narasi.tv

Penentuan media ini juga didasarkan atas perkembangan teknologi saat ini yang menjadi serba digital. Dalam hal ini, Gilaninia dkk. (2013) menyampaikan bahwa adanya dunia baru yang serba digital ini tidak membuat praktisi public relations untuk tetap meninggalkan tanggungjawabnya dalam menyampaikan informasi kepada khalayaknya dengan memanfaatkan media digital saat ini. Terlebih lagi, saat ini media sosial merupakan perangkat atau media pendukung yang dimanfaatkan oleh praktisi public relations untuk melaksanakan tugasnya sebagai public relations yang memanfaatkan keberadaan internet.

Kemudian, tahap selanjutnya adalah melakukan implementasi rencana strategis. Implementasi merupakan kegiatan merealisasikan atau melaksanakan rencana yang sudah tersusun dengan terperinci. Hal ini mencangkup jadwal pelaksanaan dan penetapan anggaran. Timeline pelaksanaan kampanye \#JadiPaham dibagi berdasarkan quarter atau tiga bulan. Dalam quarter satu atau di bulan pertama akan difokuskan untuk pengenalan kampanye \#JadiPaham kepada khalayak dengan membuat video perkenalan dan konten-konten yang berkaitan dengan \#JadiPaham. Di quarter dua akan difokuskan untuk bulan ramadhan dengan membuat kampanye turunan, yaitu \#PakaiHati. Kemudian untuk quarter ketiga akan difokuskan pada sebuah event, yaitu Playfest. Terakhir di quarter empat akan difokuskan untuk membentuk Narasi Ecosystem dengan membuat konten untuk mendapatkan anggota komunitas baru dan mendorong kontribusi dari anggota komunitas tersebut.

Untuk penetapan anggaran, komponen yang biasanya ada di dalam anggaran kampanye \#JadiPaham hanya ini meliputi video campaign dan digital activation. Hal tersebut dikarenakan adanya pandemi yang membuat keterbatasan kampanye ini hanya berjalan secara online melalui platform digital. Sedangkan untuk spesifikasi pembuatan konten, komponen yang masuk kedalam anggaran berupa hadiah giveaway untuk khalayak yang telah berpartisipasi dan pihak luar yang di rekrut untuk membantu membuat konten tersebut.

\section{Evaluative Research}

Untuk mengetahui keefektivitasan berbagai strategi dan taktik yang digunakan didalam perencanaan sebuah program, perlu dilaksanakannya kegiatan evaluasi. Selain itu, tujuan dari adanya kegiatan evaluasi adalah untuk memahami sejauh mana tujuan yang ditetapkan dapat tercapai dengan baik.

Divisi Brand Communication Narasi TV selalu melakukan kegiatan evaluasi kampanye \#JadiPaham setiap tiga bulan sekali melalui rapat evaluasi. Hal yang biasanya menjadi fokus dalam evaluasi adalah mengenai program yang sudah dijalankan dan kesesuain program tersebut dengan tujuan dan target sasaran yang sudah ditentukan. Khusus divisi Social Media Specialist memfokuskan pada aspek visualisasi, konteks informasi yang ditampilkan, dan melihat engagement dari setiap konten yang sudah dipublikasi. Hal ini dilakukan karena dengan melihat engagement sudah dapat diketahui mengenai feedback yang diberikan khalayak.

Dalam evaluasi program, nantinya hasil evaluasi akan digunakan untuk menetapkan langkah selanjutnya atau kebijakan yang akan dikeluarkan. Segala saran dan masukan dari berbagai pihak dalam melakukan evaluasi juga sangat dibutuhkan agar di program selanjutnya dapat berjalan lebih maksimal. Agar kampanye \#JadiPaham ini dapat berjalan dengan baik, yang dapat dilakukan adalah dengan melakukan pendekatan yang lebih jauh lagi dengan khalayak dengan membuat konten dan program yang dapat dipahami dan menjangkau lebih banyak khalayak. Hal ini bertujuan agar kampanye \#JadiPaham menjadi viral dan dapat dikenal oleh khalayak yang lebih banyak lagi.

\section{SIMPULAN}

Berdasarkan hasil penelitian yang telah dijabarkan di atas, maka dapat ditarik kesimpulan bahwa dalam melakukan perencanaan program kampanye public relations \#JadiPaham oleh Narasi TV, terdapat berbagai langkah perencanaan yang sesuai dengan teori "The Nine Steps of Strategic Public Relations". Hal ini mencangkup: 1) Formative Re- 
search. Di mana tim Brand Communications menemukan adanya situasi pandemi Covid-19 dan kebutuhan untuk membentuk brand identity dari Narasi TV yang mengedepankan tiga pilar, yaitu content, community, dan collaboration. Penentuan target sasarannya berdasarkan tim internal, yang merupakan karyawan Narasi TV, dan tim eksternal, yang merupakan khalayak Narasi TV dengan rentang umur 18-35 tahun. 2) Strategy. Dalam menentukan strategi, divisi Brand Communication menentukan tujuan untuk membentuk brand identity Narasi TV, melakukan interaksi dan memberikan pemahaman kepada khalayak. Untuk mewujudkannya dilakukan dengan melakukan digital activation, menciptakan produk baru, dan berkolaborasi dengan pihak eksternal. Pesan yang disampaikan mengandung nilai edukasi, disampaikan oleh komunikator yang memiliki kredibilitas dan dikemas dalam visualisasi menjadi konten yang siap untuk di publikasi. 3) Tactics. Dalam kampanye \#JadiPaham ini menggunakan pendekatan komunikasi interpersonal dengan membuat educational gathering, special event, dan memperbanyak konten yang dipublikasi melalui sosial media dan website miliki Narasi TV. 4) Evaluative Research. Evaluasi dilakukan melalui rapat evaluasi tim Brand communications setiap tiga bulan sekali untuk membahas mengenai program kampanye yang sudah berjalan. Untuk evaluasi konten dilakukan seminggu sekali dengan membahas konten yang sudah dipublikasi sekaligus melakukan perencanaan untuk konten di minggu berikutnya.

Saran yang bisa diberikan adalah dengan lebih mengaktifkan platform lain selain Instagram dan Youtube dan melakukan kerja sama dengan berbagai media dalam mempublikasi berbagai event dan workshop untuk memperbanyak khalayak. Tidak hanya itu, untuk penelitian selanjutnya, diharapkan melakukan penelitian dengan mengembangkan teori yang ada dan lebih banyak mengkaji sumber yang berkaitan dengan perencanaan program kampanye public relations.

\section{DAFTAR PUSTAKA}

Alexander, A. (2016). Sprite: 'Brutally refreshing' or sexist? Retrieved Mei 15, 2021 from https://www.bbc.com/news/world-europe36958158

Asih, D. N., \& Rosit, M. (2018). Opini Publik di Media Sosial: Analisis Isi Opini Kandidat AhokDjarot dan Anies-Sandi di Twitter. CoverAge: Journal of Strategic Communication, 8(2), 4556.
Cameron, G. T., \& Curtain, P. A. (1992). An Expert Systems Approach for PR Campaigns Research. The Journalism Educator, 47(2), 13.

Cutlip, S. M., Center, A. H., \& Broom, G. M. (2017). Effective Public Relations. Jakarta: Kencana Prenada Media Group.

Firdaus, \& Zamzam, F. (2018). Aplikasi Metodologi Penelitian. Sleman: Deepublish.

Gilaninia, S., Taleghani, M., \& Mohammadi, M. E. (2013). The Role of Public Relations in Organization. Arabian Journal of Business and Management Review (Nigerian Chapter), 1(10), 51.

Güllüpunar, H. (2013). Public Relations in Strategic Management: The Case of Metropolitan Municipalities in Turkey. Turkish Studies International Periodical For the Languages, Literature and History of Turkish or Turkic, 8(6), 218.

Herlambang, A. A. (2020, Mei 8). Dalangnya adalah Corona atau Media? Retrieved Juli 4, 2021 from https://www.ayosemarang.com/ $\mathrm{read} / 2020 / 05 / 08 / 56679 /$ dalangnya-adalahcorona-atau-media

Kristanto, V. H. (2018). Metode Penelitian (Pedoman Penulisan Karya Tulis IImiah untuk Program Diploma Farmasi). Sleman: Deepublish publisher.

Kriyantono, R. (2008). Public Relation Writing: Teknik Produksi Media Public Relations dan Publisitas Korporat. Jakarta: Prenada Media Grup.

Lengkong, M. A. (2017). Strategi Kampanye Pariwisata Kota Manado dalam Meningkatkan Jumlah Kunjungan Wisatawan : Studi Kasus Program Mari Jo Ka Manado. Universitas Multimedia Nusantara.

Putra, M. A., \& Anshari, F. (2016). Cyber Public Relations dalam Klub Sepakbola di Indonesia: Studi Pada Persija Jakarta. CoverAge: Journal of Strategic Communication, 7(1), 43-54.

Putri, R. S., \& Larasati, M. (2014). Kampanye Program Badan Kependudukan Dan Keluarga Berencana Nasional (BKKBN). Communicology: Jurnal IImu Komunikasi.

Ruslan, R. (2013a). Kampanye Public Relations. Jakarta: PT Raja Grafindo.

Ruslan, R. (2013b). Metode Penelitian Public Relations dan Komunikasi. Jakarta: Rajawali Pers.

Ruslan, R. (2016). Manajemen Public Relations dan 
Media Komunikasi. Jakarta: Rajawali Pers.

Setiawan, B., \& Fithrah, D. S. (2018). Kampanye

Gerakan Indonesia Diet Kantong Plastik Dalam Membentuk Persepsi Masyarakat Bandung. Jurnal Manajemen Komunikasi.

Smith, Ronald D. (2013). Strategic Planning for Public Relations. New York: Routledge.

Tarjo. (2019). Metode Penelitian Sistem 3x Baca. Sleman: Deepublish Publisher.

Tohirin. (2016). Metode Penelitian Kualitatif dalam Pendidikan dan Bimbingan Konseling. Jakarta: Rajawali Pers.

Yusuf. (2020). Direktorat Jendral Aplikasi Informatika Kominfo. From https://aptika.kominfo.go.id/2020/05/kominf o-temukan-1-401-sebaran-isu-hoaks-terkaitcovid-19/ 